
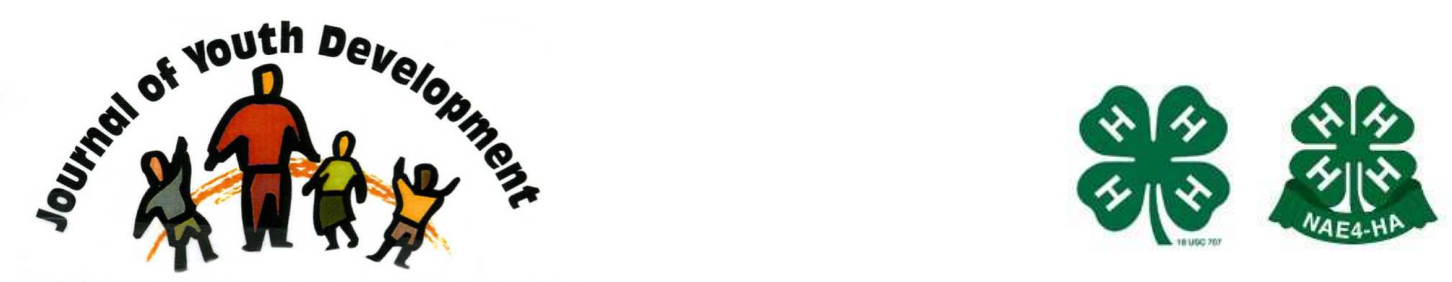

Bridging Research \& Practice

\title{
Horses - A Natural Fit for Camp Programs
}

\author{
Robin Galloway \\ 4-H Youth Development Education \\ Linn County Extension Service \\ Oregon State University \\ Albany, OR \\ Robin.galloway@oregonstate.edu
}

\section{Chris Names}

4-H Youth Development Education Josephine County Extension Service

Oregon State University

Grants Pass, OR

Chris.names@oregonstate.edu

\author{
Melanie Mintken \\ 4-H Youth Development Education \\ Linn County Extension Service \\ Oregon State University \\ Albany, OR \\ Melanie.mccabe@oregonstate.edu
}




\title{
JOURNAL OF YOUTH DEVELOPMENT \\ bridging research and practice

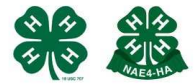

Volume 6, Number 4, Winter 2011

Article 110604PA004

\section{Horses - A Natural Fit for Camp Programs}

\author{
Robin Galloway, Chris Names and Melanie Mintken
}

\begin{abstract}
A 4-H Member's Horse Camp allows horse project members to enjoy their equine partner in a non-competitive, outdoor setting. Campers learn about leave-no-trace outdoor ethics, trail riding, maneuvering trail obstacles, equine emergency first aid, and low impact camping. 4-H has long understood that providing opportunities for youth to learn about things that interest them is just one aspect of the program. Project specific content, in this case horses, helps youth in 4-H programs to develop important life skills. In the positive atmosphere at 4-H horse camp, youth may feel a sense of belonging, and are provided opportunities to develop mastery, independence, and a spirit of generosity- which are all essential elements in high quality youth development programs. Horse camps are a natural extension of opportunities for horse project members, and they can be added to existing camps, or create new camping lessons.
\end{abstract}

\section{Rationale}

Nationwide, the majority of 4-H Horse project members board their horses at commercial stables. Many riders never venture outside a fenced arena, due to a lack of outdoor riding space and reductions in open land for trail riding (Backcountry Horsemen, 2010). Horses and riders accustomed to being in a confined space may not be mentally (or physically) suitable for riding beyond fenced boundaries (Lorimer, 2004). Riding through brush, over rough terrain, and a long way from the barn requires confidence as well as analytical and technical skills to handle one's horse. Horses are also prone to physical injury, i.e. leg sprains, cuts, etc. Youth frequently are not taught to deal with emergency veterinary injuries that can incur on a trail ride. One solution is to encourage youth to take their horses to camp.

\section{Background}

Beginning in 2002 the Oregon 4-H Center added a 4-H Members Horse Camp to the summer activities. Up to twenty-six youth, ranging from fourth to twelfth grade have participated each year. The enrollment numbers are limited for safety and to allow for more individual attention. 
This innovative program was started to allow 4-H horse project members to enjoy an equine partner in a non-competitive, outdoor setting. Both horses and mules have been the fourlegged team member. The child does not have to use their 4-H project animal. Usually their favorite equine is the one brought to camp. Youth get to hang out with their equines while learning about leave-no-trace outdoor ethics, trail riding, maneuvering trail obstacles, equine emergency first aid, and low impact camping.

In the positive atmosphere of 4-H horse camp, youth may feel a sense of belonging, and are provided opportunities to develop mastery, independence, and a spirit of generosity - which are all essential elements in high quality youth development programs (Kress, 2004).

Attending camp with their horse can strengthen the understanding and communication between the two and four-legged members of the team. The therapeutic value of horses at camps is well documented (Garst, 2003; Howard \& Howard, 2004).

\section{Horses as Tools for Life Skills}

Any camp with space for the thousand-pound equines can hold horse camps focused on educational activities. 4- $\mathrm{H}$ is a youth development organization which emphasizes utilizing projects (i.e., horses) as the tools for life skills. With this in mind, the objectives of having horses at camp are:

- Allow youth to partner with their equine in a non-competitive natural atmosphere

- Instill environmental awareness and low impact ethics in youth

- Develop confidence and competency in dealing with equine medical emergency first aid

\section{Tight Reins on Safety}

The American Camp Association (ACA, 2001) Accreditation Standards for Camp Programs and

Services has a section on horseback riding. As in other specialized program activities, safety is a central concern. ACA's Horseback Riding standards set high expectations for trained supervision, appropriate instruction, safety precautions, and well-planned emergency procedures. ACA standards closely align with $4-\mathrm{H}$ rules. All riders are required to wear ASTM certified helmets with a harness when mounted. Boots with a hard toe and heel must be worn when handling horses or riding. 4-H horse leaders are trained to work with youth and understand horses. These experienced adults with seasoned trail horses are involved in all aspects of the camp-from planning, implementation, and evaluation.

\section{Facilities}

The horse camp at the Oregon 4-H Center is a separate facility located a five-minute walk away from the core area. Horse camp consists of a large historical barn, a grassy meadow, a $100^{\prime} x$ $200^{\prime}$ fenced riding arena, water troughs by the barn and arena, tack shed, bunkhouses, covered barn with stalls, outdoor individual corrals, bathrooms, shower house and a small kitchen. There are scenic and safe riding trails around the 320-acre facility.

Camps which do not have such extensive amenities can still include horses in the camp structure. Wilderness management techniques such as keeping horses on overhead "tie lines," and portable corrals provide temporary housing for animals. When horses are on the camp property, specific risk management plans must be implemented. 4-H horse project members are covered by an accident insurance at any camp or 4- $\mathrm{H}$ function they attend. 


\section{Camp Financial Scholarships Apply}

Since horse camp is one aspect of the Oregon 4-H Center's camps, the costs are minimal. Campers pay for meals prepared with the main 4-H camp. Each rider brings all necessary feed for their equine. Grants have helped cover part of the participant's cost each year. As one parent noted, it's much cheaper for her daughter to attend three days and two nights at horse camp, than do one day at a horse show.

\section{Program Contents}

People love to share their passion and expertise about equines. Over the years a variety of organizations and professionals have been recruited to teach at the camp. To emphasize the Leave No Trace educational portion, hands-on demonstrations are provided by certified instructors from equestrian trail riding organizations. The Backcountry Horsemen of America (2010) has chapters in many states with volunteers who attend camps and provide educational programming. At the Oregon camp, horse and mule packers with the US Forest Service have been guest speakers. Campers are treated to meeting pack animals, practicing balancing loads on the mules, seeing what a wilderness camp entails, and learning low-impact camping techniques-all in a field at the Oregon 4-H Center. Fancy facilities are not needed to replicate the wilderness equine experience at any camp.

Senior students from the Oregon State University veterinary school have taught hands-on emergency first aid classes. The key concept emphasized is that every person needs to take responsibility for dealing with equine medical emergencies. Campers are taught to take their own horse's temperature, pulse, and respiration; to stop bleeding; and to wrap injured legs. Some of the campers do not want to take their horse's rectal temperature - however they learn that horses cannot hold a thermometer under their tongue. Experienced 4- $\mathrm{H}$ horse leaders and Extension agents assist the youth in safely practicing hands-on first aid at horse camp.

\section{Project Outcomes: Survey Results}

Every year, all campers complete a retrospective pre-post test at the end of camp. Follow-up evaluations have been conducted six months after camp. Youth reported gaining general horse knowledge, new ideas, new skills-and they learned to apply these new skills. When asked what benefits had resulted from attending the camp, youth reported feeling more comfortable riding on the trail and being competent to handle emergency first aid.

Questions covered knowledge, attitudes, skills, and actions. Significant differences were seen in each area in a majority of campers. For example:

- Understands low impact camping

- Feels confident to take horse's 3 vital signs (temperature, pulse and respiration)

- Improves condition of horse before hard rides

- Comfortable teaching trail riding to others

The 2003 follow-up evaluation had an 82 percent return rate (19/23) and showed that the youth retained what they had learned and were using their knowledge when trail riding. This finding was especially significant because riders reported they were making changes in their riding habits during the winter, when most trail tread damage occurs. 
In 2006, a slightly different format was used. 4-H horse project members and their families were invited to bring their horses to the Oregon 4- $\mathrm{H}$ Center for a long weekend. Instead of focusing on structured educational activities, the theme was a work party. The participants worked, rode, and played hard. They cleared brush from trails, put gravel into stalls, fixed fences, etc. The camp physically benefited by the campers' attendance-a welcome twist for any facility! One parent attended camp to try and learn why her daughter spent all her free time with her 4-H horse club. At the camp wrap-up session, the mother commented on how impressed she was with her daughter's friends, their commitment to their horses, and the skills they were all learning in their $4-\mathrm{H}$ horse projects.

\section{Benefits of Horses at Camp}

Camps and campers both benefit by allowing campers to bring their own horses to camp for educational, structured events. There are a growing number of 4-H horse project members who do not have the opportunity to ride their horse in a "natural" outdoor environment. They should be able to enjoy nature and riding, with knowledge to protect themselves, their horse, and the environment. The 4-H Horse camp addresses all these issues in a relaxed, non-competitive way. The format used in Oregon can be easily modified anywhere.

\section{Future for the State 4-H Horse Camp}

Evaluations from the past few years reveal that youth and parents want the camp to be longer. Some reasons include:

- Many youth travel long distances to get to the 4-H Center

- They want more time to trail ride

- They want more specific education about their equine companion

- More time to just hang out with their horse and new friends in the woods

In response to these requests, there will be one more day and night added to the $20114-\mathrm{H}$ Horse Camp.

\section{References}

American Camp Association. (2001). Accreditation Standards for Camp Programs and Services.

Backcountry Horsemen of America. (2010). Public Lands Forum.

Garst, B.A. (2003). Benefits of camping: Youth development through 4-H camping. Virginia Cooperative Extension. Publication 388-102.

Howard, T., \& Howard, A. (2004). Horses and the Wilderness - Meeting the Needs of Youth at Risk. Camping magazine March/April 2004.

Kress, C. (2004). The Essential Elements of 4-H Youth Development. West Virginia University. [On-line]. Available at http://www.nis.wvu.edu/2004 Releases/n4release.htm

Lorimer, R. (2004). Success With Horses = Success With Life. Camping magazine March/April 2004. 


\section{Biographical Information:}

Robin Galloway is a 4-H Youth Development Associate Professor with Oregon State University in Linn County, Oregon.

Chris Names is a 4-H Youth Development Assistant Professor with Oregon State University in Josephine County, Oregon.

Both work with both day and residential camps at the Oregon 4-H Center near Salem, Oregon. They were professional horsemen in previous lives, training both equines and humans to communicate better as a team.

Melanie Mintken is an Educational Program Assistant with Oregon State University in Linn County, Oregon. She works with youth of all ages in traditional 4-H clubs and special programming.

(c) Copyright of Journal of Youth Development $\sim$ Bridging Research and Practice. Content may not be copied or emailed to multiple sites or posted to a listserv without copyright holder's express written permission. However, users may print, download or email articles for individual use. 